\title{
Vegetable Temporalities: Life cycles, maturation and death in an Amerindian ethnography
}

Joana Cabral de Oliveira'

'Departamento de Antropologia, Universidade Estadual de Campinas, SP, Brasil

\begin{abstract}
This article considers how relations with certain plants produce multiple temporalities for the Wajãpi, an Amerindian people from the Brazilian Amazon. Inspired by a non-anthropocentric anthropology or an "anthropology beyond the human," the article is an ethnographic exploration about how the Wajãpi perceive the concrete and sensible features of certain vegetable species, and thus how they see them as subjects, in a process that produces different space-times. I also show how certain concepts are central to this same process, specifically, that of life cycle and maturation (including death), which lead to notions of co-temporality and difference between groups and individuals.
\end{abstract}

Key words: maturation, temporality, amazonian ethnology, plants.

\section{Temporalidades Vegetais: Ciclo de vida, maturação e morte em uma etnografia ameríndia}

\section{Resumo}

Esse artigo se volta ao modo como espécies vegetais produzem multiplas temporalidades entre os Wajãpi, um povo ameríndio que habita a amazônia brasileira. Inpirado por uma análise antropológica não-antropocêntrica ou por "uma antropologia para além do humano", o artigo é uma exploração etnográfica sobre como os Wajãpi percebem as dimensões concretas e sesíveis de certas plantas, e como eles as compreendem como sujeitos, em um processo que produz diferentes tempo-espaços. Também demonstra como certos conceitos são centrais nesse processo, tais como as ideias de ciclo de vida, maturação e morte, o que conduz a noções como as de co-temporalidade e a diferença entre grupos e indivíduos.

Palavras-chave: maturação, temporalidade, etnologia amazônica, plantas. 


\title{
Vegetable Temporalities: \\ Life cycles, maturation and death in an Amerindian ethnography
}

\author{
Joana Cabral de Oliveira
}

“To see a world in a grain of sand

And a heaven in a wild flower,

Hold infinity in the palm of your hand

And eternity in an hour."

William Blake, Auguries of Innocence, 1805

\section{Canopy: an overview of the context and the questions it raises}

Plant beings are central to the construction of space times by Wajãpi families, as I observed while walking through the gardens and forests that compose their world'. In this context, the relevance of sensible dimensions is very clear, leading us directly to Lévi-Strauss' (1966 [1962]) "science of the concrete," in which these dimensions are made of "discoveries of a certain type: those which nature authorised from the starting point of a speculative organisation and exploitation of the sensible world in sensible terms." (Lévi-Strauss 1966: 10). Although a detailed description of the concrete elements that make up the Wajãpi's knowledge of plants is beyond the scope of this article (see Cabral de Oliveira 2012), we can identify how these sensible dimensions operate here by considering a specific aspect: vegetable temporalities manifest through plant diversity and through a broad, plastic and motile scale of doing, thinking and relating to different space-times.

The Wajãpi are Tupi-Guarani speakers who inhabit a region along the Jari River in Brazil and the headlands of the Oiapoque River in French Guiana. I work with families who live on the Wajãpi Indigenous Land (WIL) on the Brazilian side and who move throughout their territory, occupying small villages at the limits of the WIL during the dry season and concentrating in large central villages - regional conglomerates made up of small clearings that surround state institutions such as schools and health posts - during the rainy season. These movements currently also follow the secondary school calendar, which is set by the Brazilian Federal Government. Despite the increasing number of Wajãpi families with salaried individuals, their food requirements are obtained from gardens and by hunting, fishing and gathering. Their way of life thus also involves daily movements, including incursions into older growth, and secondary growth forests, gardens, floodplains and streams.

The diversity of landscapes named and recognised by the Wajãpi can be distinguished, up to a certain point, as either gardens (koo) or forest (ka'a). The gardens are spaces created by families in sections of the forest that they tame by slashing, burning and planting, constituting places appropriate for humans. Villages are built over those gardens and can thus be understood as extensions of the koo domain, both villages and gardens are composed of cultivated plants (temitãgwerã, which means "planted", the most inclusive category of Wajãpi taxonomy). Meanwhile, the term ka'a - often translated as forest - includes all those spaces that are neither

1 I have worked with Wajãpi families since 2004. 
gardens nor their extensions (a former-garden that is now secondary growth forest, kookwerã; a village, taa; and a former village, taapererã). Ka'a is composed of non-cultivated plants (temitãe'ã, literally "not-planted”) and in some speech contexts the term may also encompass forests, rivers, mountains, etc. We can thus begin with an initial differentiation between the koo and ka'a domains, where the garden is a space for sociability and consanguinity among humans, as affective memories are made through cultivated plants, while the forest belongs to others: it is the domain of the most dangerous cosmological owners - the ijarã - and their pets (the creatures that they care for and over which they are extremely protective).

The forest is well-known as a field of affinity and alterity but this does not mean that the Wajãpi distance themselves from it. Irrespective of the inhabitants of the ka'a's potential for aggression, Wajãpi families form close ties with them and have detailed knowledge about their bodies, affects, behaviour and moods. They can also disguise potentially distant relations with these beings through the use of consanguineous titles when faced with certain dangers. For instance, to prevent heavy clusters of Brazil-nuts from falling on their heads during the harvest, they enter the forest cautiously, addressing the Brazil-nut trees as grandfather (FF or MF) and ask them not to throw down their fruits. They may also refer to a roaring jaguar encircling a camp as grandfather. The Wajãpi hope that this approach will acquiesce the forest's inhabitants. The forest also contains memories of a remote past, bearing the marks that spatialize formative events and making them present, and thus allowing the Wajãpi to imaginatively experience the jane ypy (our beginnings).

Meanwhile, the gardens and their extensions are marked by cultivated plants (temitãgwerã) that carry the affective memories of kin, of different moments in life, of people's growth and ageing. Despite the intimacy established with these plants and clearings, they can also be aggressive and demand a specific type of conduct: people who are sick and women who are menstruating or have just given birth must follow several prescriptions, which include not going to the gardens and refraining from all harvesting activities. This is because these conditions can anger the plants' cosmological owners (ijarã), the most feared of which is the manioc owner. ${ }^{2}$

By considering the Wajãpi's active relations with plants (referring to the Western category that encompasses the opposing folk categories of temitãgwerã and temitãe'ã), in the reflections that follow I will describe the processes involved in living and elaborating different space-times in this setting. At first, the description and analysis consider the binaries garden versus forest and planted versus not-planted but as the complexity increases certain twists and turns emerge that prevent a simplistic conclusion. Inspired by the Wajãpi, I hope to portray the plants as subjects (as "agents of meaningful acts", Pollock 1996: 323). To this end, I establish a dialogue with anthropologies that aim to destabilise humanity's significance, such as Bateson's (1979) concept of "mind"; Haraway's (2003a and 2003b) notion of "companion species"; developments of this notion by Tsing (2012) and Van Dooren (2011 and 2012); and more recently Kohn's (2013) “anthropology beyond the human."

\section{Purpose and Contributions}

In relation to Amazonian ethnology, the aim is to open a new path within a well-established debate about space-time, which is firmly based on the analysis of shamanism and ritual, and that will be raised here through the daily, sensible relation between the Wajãpi and plants (temitãgwerã and temitã'e'ã). In this way, I hope to show that plants can be drivers in the passage between a (mythic) time of origins and a time of kinship.

\footnotetext{
2 In this case, we are dealing very simply with cultivation (care given to plants) and not with a relation of domestication, the process by which an organism's reproduction and survival depends on humans. The plants' cosmological owners are also responsible for them and thus cultivation does not imply domination or dependence; we might even call it a relation of co-caring or "shared custody."
} 
The focus of this effort falls on the life cycles of various species and how the Wajãpi compare and create commensurability between them. The focus on plants allows for an alternate view of the questions raised by Amerindian perspectivism (Viveiros de Castro, 2002), such as the generalisation of a human condition, as something that is common to all beings and which defines the position of subjects.

Post-human anthropology seems like another way to approach the focus of this article, which also hopes to contribute ethnographically to this novel theoretical approach. At the same time, an effort is made here to move away from commonly analysed dyadic relations, such as humans and animals or humans and plants, through an ethnographic comparison of the relations established with both primary groups of organisms, as well as with objects. Another contribution is to reflect on inter-specific relations that operate at different levels of abstraction, specifically at the level of the individual and the group (or category). The analysis also strives to invert the vectors of action, locating plants as agents in and of relations. More than as supports for thinking about temporality, they make the Wajãpi remember, which allows for the emergence of distinct space-times. Here, Lévi-Strauss' contemplation of mythic temporality and action will be connected to the life cycles of organisms and consequently to Darwin's theory of evolution. In this context, scientific studies conducted by botanists seem like a reflexive solution to the effort to invert the vectors for action and understand the agency of plants without invoking Amerindian perspectivism. By tracing partial connections between Wajãpi and scientific knowledge, the article explores notions of inter-specific communication (a semiotics of nature, as Kohn, 2013, would say) or the configuration of a cybernetic circuit (a mind system, as Bateson, 1979, would say). Another contribution to post-human anthropology is therefore presented by the possibility to partially connect disparate knowledge regimes.

\section{Great Ageing Trees (The Space-Time of Origins Accessed by Vegetable Bodies)}

Some of the mythical accounts that I had the privilege to listen to during fieldwork were triggered by questions surrounding the name of a tree or plant. On one occasion, from the village clearing I saw a Parkia pendula and this beautiful tree caught my attention due to the red blooms that hung from its long stalks, and which were distributed throughout its flat canopy. When I asked the name of this tree I was given a first-times story, which I transcribe here to transmit its narrative style: 3

"Long ago the sky fell.

Friends played. The ancestors' children played while the butterflies tied up the sky. The children picked cotton flowers, drew them together and spun them. "Butterfly weri ${ }^{4}$ like me," said one uncertain butterfly. "They are my kin," said another butterfly uncertainly. So, many butterflies came down. The ancestors' children killed them all by using baskets to cover them. The butterflies gathered once more and came down again. They gathered with the cotton flowers in the clearing. Baskets were thrown over them once more. Once more, they were killed. Children are like that, they kill things just like that.

The ancestors had gone out and that is why they didn't see that the children had killed the butterflies. The old chiefs only saw the deed later: "What did you do, kill all the butterflies?!"

It was already late and the dawn wouldn't come. The sky had fallen.

Did the falling sky make a sound? The forest held it up, that's why the sky didn't fall to the ground. What was it that held the sky when he fell? It was the jiruru tree [Parkia pendula].

\footnotetext{
3 This narrative was recorded in Wajãpi and I translated it to Portuguese.

4 Weri butterflies belong to the Phoebis genus (sulphur butterflies). I am grateful to Dr. Blanca Huertas for this identification. It is important because it provides a telling characteristic: this species is yellow, in a tone similar to cotton flowers.
} 
That is why it's canopy is flat now. During first-times, long ago, our owner made the jiruru, he became a tree.

Later, when the sky fell, there was a deep darkness. Why did the ancestors not scold [the children]?: "Why did you fight with the butterflies?" that's what they should have said to their children. Why didn't they say: "Night will no longer break!"

But Janejarã [a demiurge, literally 'our owner/master'] was still in the forest, on land: "You killed all the butterflies that's why the sky fell. The butterflies tie-up [the sky at] the edge of the land. The edge of the sky comes down and the butterflies tie it to the edge of the land end," he said.

After the sky fell the elders asked: "How do we lift up the sky? We cannot exist without dawn."

"Come and make the jupara [kinkajou, Potos flavus] party", said Janejarã. The women went to the garden in the dark, using resin to light their way. The women made kasiri [fermented manioc]. "You should play jupara!" said Janejarã. "The jupara songs will lift the sky high. You should sing jupara to raise the sky."

They finished making kasiri and made resin torches in the dark. The men lit the resin. Then they brought them together and they played marakaja [ocelot, Leopardus pardalis], jupara and other songs. The night became beautiful, they played. And the night became beautiful like this one. The sky went up. Janejarã listened attentively to the party. The sky went up round as a gourd, very beautifully, the sky went high as thunder.

"Now dawn will really break," said our ancestors. "The cock didn't sing, now the cock knows, the dawn will come and when it does the cock will sing." And they played until dawn. They continued to play until after it had dawned, the sky sprouted and went far, the sky went far, such as it is today. "The jupara party makes the sky go up," said our grandparents. That is why we don't kill butterflies, the sky may fall.

Jupara is a good party, in the past it made the sky go up. Replicas of the jupara fruit are made of curassow [Cracidae] feathers, macaw feathers... and resin ... Then we play and hang these replicas of the jiruru fruit [on the flutes]. That is what our grandparents told us in the past."

On another occasion, while walking down a forest path, a wooden vine caught my attention due to its strong stalk, which was almost the size of a tree-trunk and delicately twisted down an enormous tree. I asked one of the Wajãpi who I was following for the vine's name: "it is called japuamyu [japu bird mucus]". On recognising the composition of the name I asked why it had this name, which led him to tell me a long story. It turned out that the japuamyu (Bignoniaceae) vine was a reminder of another first-time event. The story tells of the adventures of a demiurge called Wyrakauri and his brother-in-law and their effort to fetch a sparrow-hawk chick from the top of a tall sumaúma tree (Ceiba pentandra). At one point, Wyrakauri climbs up a slender tree that stands by the sumaúma and crosses over onto the larger tree's canopy, using a branch as a bridge. As a prank, his brother-in-law removes the bridge, leaving Wyrakauri stuck in the nest. A series of events takes place during which a number of different birds try to help him down but only the japu (Cacicus cela) succeeds: he snorts through his beak and lets his mucus run down to the ground, which becomes a vine that Wyrakauri uses to descend.

The ajãpiry tree (Calycophyllum spruceanum) is another good example. One of the mythical motifs that I heard on numerous occasions during my fieldwork is of how humans became mortals. In these accounts, Janejarã invites the first Wajãpi, taivïgwerã, to bathe in his cauldron's boiling waters but they decline because they are suspicious, and fear being burnt. Instead of the first humans, it was thus the snakes, lizards, cicadas and other insects that bathed in the bubbling waters and who can now change their skins: a sign of eternal youth and immortality. At the end of the story, Janejarã throws the rest of the water away and it falls on the ãjãpiry tree, which thus becomes like those animals and can constantly change its bark: its dry wooden brown skin eventually cracks and falls, giving way to a smooth shiny green trunk.

The point is that the forest is full of markings that make past events more than memorable. Temporality is thus spatialised, providing access to an inescapable past that is inscribed in the trees and many other beings, a past that is activated in the present to make the world's current configuration intelligible. 
Some Americanists - such as Overing (2006), Hugh-Jones (1979), Viveiros de Castro (2002), Gow (2001) and Saez (2005) - have discussed mythic temporality through the analysis of shamanism and ritual, and have ethnographically shown how mythic narratives do not only refer to the remote past. In shamanic negotiations (involving treatments for diseases, help with hunting, revenge, etc.), shamans deal with animals and other beings in their human condition while sharing a common language with them. Thus, as Saez concludes for the Yaminawa, "the extraordinary facts narrated [...] identify a synchronic rather than diachronic distance; animals speak from another current time, which is shamanic time" (2004: 43). And as Hugh-Jones states about the Tukano: "it should be clear from the material [...] that the ancestral past is also an alternative aspect of the present which can be contacted through shamanism and ritual" (1979: 235).

However, while access to a mythical space-time has been well-established via shamanism and ritual, what I would like to point out here is that it can also be reached through an alternative relational path, one that operates through the sensible and imaginative 5 faculties. Forest inhabitants carry their ontogeny and make it explicit in their bodies, allowing us to establish connections between distinct space-times through sensorial experiences. The jiruru's flat canopy is thus an indelible mark of the sky's collapse but it also reminds us of the current condition of the cosmos: it is a flat plane in which butterflies must constantly work to tie the sky and land together at their edges. Likewise, the jiruru make it impossible for the Wajãpi to forget the jupara and many other festivities.

\section{Planting Affect, Remembering Kin}

How can we connect the scale of an ancient space-time with a recent past that is closer to a human lifespan and to personal memories? One option is to consider how cultivated plants directly refer to the cycle of affective memory among kin: memories can be planted through them, as we will find in the descriptions that follow.

An old chief called Waiwai brought some patauá palm (Oenocarpus bataua) seeds back from a visit to French Guiana and presented them to his wife, Parua. I was with her that morning in her courtyard as she spoke to her grandchildren, who surrounded their grandmother while she distributed the pataua seeds among them. She then used a hoe to dig some small holes in which the children lay the seeds. Later, Parua explained that she had called on her grandchildren to plant the patauá because they were unfamiliar with that palm tree: "They have never seen it, later it will sprout for them to see." However, it was also clear from our conversation that this was not just an instructive act: it involved creating a childhood memory for her grandchildren. According to Parua, when her son was small she had him plant a pino'e'e palm (a variety of bacaba, Oenoarpus bacaba) and when the pino'e'e palm had grown, her son had become an adult. The maturation of the palm and her son were thus entwined. Planting and the care given to the palm and child were interlaced in both subjects: her son's memory of growing-up was manifest in the palm and vice-versa. Parua's act can thus be understood as creating a qualitative index, ${ }^{6}$ a fundamental step in making and transmitting Wajãpi knowledge (Cabral de Oliveira 2012). Parua established a nexus of commensurability between her son and a pino'e'e palm, creating an index of maturation: a mark that commensurates these processes.

\footnotetext{
5 I understand the imagination to be the capacity to virtually place oneself (not to actually do so, as do those who possess shamanic capacities) in other space-times or perspectives. Some authors have made use of this term without giving it the status of an anthropological concept (Ingold, 2013; Hughes, 2002). Following Thompson: "The imagination is not a source of error or illusions, but an ability to feel that which one does not yet know, to intuit that which cannot be understood, to be more than what is conceivably known" (1987: 8).

6 The notion of index necessarily refers us to Charles Peirce, who defines it as an indicating sign that makes inference possible (apud. Gell, 1988). Alfred Gell adds a semantic charge of agency to the Peircian concept in his proposal for an anthropology of art. Eduardo Kohn (2013) also borrows Peirce's concept, according to Kohn, the characteristic property of an index is its capacity to signify more than it represents, opposing it to the notion of icon, which represents itself (Ibid. :32-33).
} 
This type of action is extremely common among the Wajãpi: the peach-palms (Bactris gasipae) planted by a deceased chief index his presence for his wife and children; although a deceased person's belongings are buried and abandoned along with the village where the corpse is buried, her crops (especially those that last longest, such as palm and fruit trees) remain, spread out in the area that she once occupied, reminding everyone of her wanderings and stories, and marking each wãn's (local group's) area. This is why it is common to identify specimens planted by certain people - who may be deceased - when passing by old gardens and villages, and to remember and relive the ties that bind people in a network of relationships and places.

This not only happens with specimens (which are individual) but also with varieties (groups). Once Kasawa told me that upon returning from her garden she found that her tapupura cotton plant (a variety of Gossypium) had been cut down: "I cried when I saw that my son had cut my tapupura cotton! I became angry. I said: 'Why did you do that?' I cried a lot that day, I was sad because it is very difficult to find tapupura cotton, my mother had given me the seeds." Although Kasawa was sad in relation to a specific plant, she had other tapupura cotton plants that were also planted with seeds given to her by her mother. She continues to be reminded of her mother by all of the tapupura plants that she has planted or will ever plant, for memory is linked to a variety of plant, which operates as a lineage as long as it is continuously (re)planted.

Every woman knows the origins of her plant varieties and the story surrounding the acquisition of each variety is connected to its name and not just to a specimen, for each variety is annually replanted in a new garden or courtyard. The gardens are thus veritable collections of maniocs, sweet potatoes, cottons and so on, each with their own origin stories (Cabral de Oliveira, 2009; this can also be seen in other ethnographic contexts, such as Hugh-Jones 1979, Rival 2001 and 1998 and Murrieta et. al. 2003).

\section{Comparisons: approximations and discontinuities between plants, animals and objects}

Although my work emphasises the Wajãpi's relations with plants, I would be unable to fully account for the implications of these relations if I restricted our attention to the vegetable kingdom alone. In fact, to broaden our reflection beyond the Western distinction between living and non-living beings or animals and plants - particularly given the importance attributed to human-animal relations in Amazonian studies in the last two decades (Viveiros de Castro 2002, Garcia 2010, Lima 1996, Fausto 2008) - it is useful to raise some of the spatio-temporal connections that the Wajãpi establish with animals, as well as with objects. Thus, as Santos-Granero does through his critique (2009) of the theoretical invisibility of objects in Amerindian studies, I also hope to highlight the non-exclusiveness of certain aspects of human-animal relations.

As already mentioned in the case of snakes, lizards and insects who change their skins in a constantly rejuvenating cycle, animals can also carry ontogenic marks on their bodies. The colours of different birds' plumage is another example. Generally, the Wajãpi attribute these colours to a primordial festivity in which each bird - at a time when they were all people - painted itself and sat in a sumaúma tree's branches (which also gave all sumaúma branches their current shape). At the same time, according to an episode of the mythic saga about Janejarã's (Our owner's) twin sons, many different birds received their markings while trying to help the twins to obtain fire from the vulture, its owner, by stealing a burning ember: while attempting this feat, the spix's guan (Penelope jacquacu) swallows the ember, leaving the red wattle seen on its body today; the toucan (Ramphatos spp) burns its beak, which leaves a black spot; the clumsy trumpeter (Psophia crepitans) falls into the embers, which is why the back of its plumage is grey; and so on. These examples are enough to indicate how animals seen today also trigger the imaginative experience of an ancestral space-time.

However, the clear equivalence between forest animals and plants in relation to a primordial space-time is not repeated in the domestic sphere. It is therefore common, for example, for Wajãpi families to rear the young of birds and mammals captured in the forest and to establish relations equivalent to filial ties with them during 
the process of taming, by sharing their food with them, anointing their bodies with annatto (Bixa orellana), sharing common spaces, etc. The criteria they employ for the constitution of domestic animals (xerimbabos in a Tupi-derived Portuguese term and -reima in Wajãpi) can be inversely demonstrated through observations made during fieldwork in relation to the practice of rearing agoutis (Dasyprocta sp.) for consumption. According to Nazaré, for example, these agoutis could be killed and were not xerimbabos both because they remained in a pen separate from the village's communal living space and particularly because they were not fed with the same food as her family.

Although xerimbabos establish relations of extreme proximity and affect with the people that rear them - following their owners wherever they might go - unlike cultivated plants, they are not sources of distant memory. I would argue that this difference is due to the vegetable (sensible) peculiarities involved in rearing animals and plants. Unlike plants, xerimbabos are not perpetuated through a lineage because their shorter life-cycle and incapacity to reproduce themselves in the domestic context erase mnemonic ties at death. Meanwhile, manioc, cotton and many other plant varieties are perpetuated in time, traversing and connecting different generations and social groups. Since lineages last longer than the lifetimes of individuals and since plant lineages do not perish (unless they stop being cultivated), certain plants become long-lasting relational vehicles that obliterate the passage of time. Concurrently, the longer life-cycle of palm and fruit trees, and their permanence in specific places, make the peach-palm or cotton tree into fixed material marks that tie space and time together.

Finally, it is also worth inserting objects into the broader picture given their known importance in Amazonia (Santos-Graneiro, 2009 and Van Velthem, 2003). In the Wajãpi case, we can identify the agency of certain artefacts, as well as their relevance to the mythical genesis of a number of living beings (which Santos-Granero calls "Amazonian constructional cosmologies"): in the aforementioned mythical twins saga, specific objects become aquatic animals when they come into contact with floodwaters, such as a mat, which becomes a fish known as paku (Myleus spp.). Much like plants and animals, certain objects can thus appear as the mnemonic sources of cosmogenic events.

In terms of the temporalities that refer to kinship and to a person's life-cycle - while cultivated vegetable species have a central place - objects do not stand out as subjects that activate memories, since a deceased person's things are buried and abandoned together with the body. It is therefore possible to compare concrete objects (that are made and owned by a certain person) to xerimbabos, and thus indicate their short life-cycle: which is short because the majority of objects manufactured by Wajãpi families (with the exception of ceramic pots) are made from perishable materials that last very briefly in a tropical climate. Their life cycle is short because objects made or used by someone who dies (including objects with greater durability such as ceramics and industrialised goods) should be buried and abandoned since they carry with their owner's substance and can cause illness in living relatives. Wajãpi families often come across potsherds, stone axes and even whole ceramic vessels when making their gardens in very old secondary growth forests. As well as being dangerous, these objects are the topic of long discussions among those who find them: in each case they recount certain stories and evaluate whether the objects belonged to their generic kin or to their enemies.

Such finds thus allow for the emergence of different temporal and mnemonic registers, a theme already explored by the archaeologist Mariana Cabral (2014) and which I cannot develop here. What I would like to emphasise is that what is at stake is not exactly an opposition between living and non-living beings. We cannot understand the world presented by the Wajãpi - where objects ${ }^{7}$ have agency in the present, reflecting a condition given in a primordial space-time in which axes and pots do work by themselves - by projecting our own separation between living and non-living beings. What seems important is thus to think about the

7 We can include lakes, mountains, rivers, landscape and other components that are also imbued with agency and carry marks that remind people of primordial events. 
concrete temporality afforded by these entities in their elaboration of the multiple space-times that compose the Wajãpi universe. Contrary to Kohn (2013), I do not apply and reflect through our separation between living and non-living, but set out from the Wajãpi ethnography to understand how cycles that begin and end are qualified in a cosmos where agency is broadly distributed. The question here relates to the temporalities that belong to the bodies of each being (including objects), that is, their cycles of duration, maturation and transformation, and I will now focus specifically on the emergent temporalities of botanical diversity.

\section{Engagements and Vegetable Temporalities}

The Lévi-Straussian maxim that "animals are good to think about" has undergone minor changes in recent years. According to Ingold (2000) animals are "good to relate to"; while Mosko (2009) looks at the relation between Melanesians and yams, and affirms that they are "good to act with"; and Haraway (2003a) uses her notion of companion species to insist that "animals are good to live with." Notwithstanding the advantages of these conceptual nuances, the central point is that the non-humans ${ }^{8}$ with whom we construct and share a world should be understood as relational subjects. This is particularly evident in the Amazonian context, where this subjective condition means that the cosmos' various inhabitants need to be carefully dealt with and related to: one can therefore potentially avoid a fatal attack by calling the Brazil-nut tree "grandfather".

What emerges from the descriptions presented here is thus a way of acting in a socio-cosmic network. At times, this involves active constructions by Wajãpi mothers, grandparents, etc. - as in the memories entwined with cultivated plants - and at other times in memories made by a cosmos that leaves traces of its transformation. That is, it involves a cosmos that also acts and communicates through and with plants (and/ or animals and objects). In both cases, the plants that lend themselves towards the elaboration of memories diverge significantly from each other in terms of life cycles and maturation. Therefore, while large trees such as the jiruru, ajjapiry, sumaúma, and the japuamyyu vine grow slowly and last for hundreds of years, the plants that materialise affective memories mature quickly and have short life cycles. As a result, the latter have more malleable interactions with humans: they are constantly replanted and altered in a process of multiplication, accumulation and loss of variety (or forgetting). Their temporality allows for a more global perception of maturation processes and reactions by the two parties (people and plants) that form a relationship.

Hugh-Jones (1979) and Rival (1993) have already drawn attention to the Tukanoan and Huaorani interest in plant maturation and its relation to social processes. Hugh-Jones thus describes Tukanoan analogies between human growth and manioc processing, while Rival shows how the Huaorani's sophisticated understanding of plant development is used to qualify social maturation processes, and to act on the transformation of children into adults. The Wajãpi do not explicitly speak about these issues but it is possible to argue that their engagements with various plants involve a detailed perception of their specificities (including morphological characteristics, maturation and life cycles), and that this perception guides a complex system of attitudes and relations. Assorted plants provide them with the experience of multiple times and thus vegetable temporalities are as diversified as the biodiversity that constitutes them.

\section{First Twist: Individual and Group, Myth and History}

Until now I have described a stable dual composition - forest: origin space-time; vegetable garden: kinship space-time - that is also related to the separation between myth and history in anthropology; an extensive debate that is beyond the scope of this study. Nevertheless, Gow (2001) and Gallois (1993) have

8 Since non-human subjects are not restricted to animals and plants, but also include rocks, rivers and objects, the idea of a companion species can and should be extended to what is thought to be inanimate and inorganic in the West. 
made observations about Amerindian peoples that are relevant here. In Lévi-Straussian inspired analyses, these anthropologists ethnographically argue that the intensely open and transformational qualities of myths make them historical objects. In the Wajãpi case, Gallois describes how a myth can converge with and insert itself into a historic narrative (an account with named ancestors) when a new experience or situation allows for the myth's revaluation. Meanwhile, among the Piro, Gow refers to a temporal axis with two poles: one of personal experience - relating to named subjects that are known as kin (history) - and another that describes events enacted by demiurge (myth). According to the author, between these poles, processes are found that combine myth and history. Along with Lévi-Strauss, both authors contextually point to the relational complexity of myth and history, emphasising the various transformations that these narrative genres and temporalities can undergo.

The material that guides this article, based as it is on a Wajãpi ethnography in which movement is seen to be fundamental to life ${ }^{9}$, also destabilizes this binary frame and complexifies the analysis. For example, the Wajãpi clear annual gardens in forested areas and abandon them after a harvest of short-cycle crops, these gardens gradually become forest again after passing through secondary growth stages. As such, if the very opposition between garden and forest that is so important to Wajãpi life includes movement, the temporal setting that contrasts these domains cannot be as inflexible and standardised as described until now.

First-times can also be present in the bodies of cultivated plants, as in crops that sprouted when the body of a puss-ridden old woman was burned: manioc emerged from her shins, corn from her eyes, yam from her feet, papaya from her breasts, bean pods from her vagina, and so on. Independent of the variations that each version of this myth presents, what matters is the relation of similarity of form between body parts and vegetable species. Cultivated plants can therefore also present the corporeal signs of their ontogenesis and, likewise, large trees can be reminders of recent events linked to a human life span. During the move to a hunting camp near the Tawariry River, upon passing by an enormous yvyra pirã tree (I was unable to identify the Latin name for this species), I heard amidst laughter the story of a kinsman who missed a shot on a coati (Neusa sp.) that ran up its trunk. In another example, presented in Cabral (2014) in the account of an expedition to the Ypavu lake, the Wajãpi elder who led the way found an old path that he had not taken since his childhood by recognising some machete marks: scars left decades earlier on the durable trunks of ancient trees.

We are thus faced with non-lineal series that prevent the use of a stable explanatory schema, yet one more point of differentiation is required here for us to move forwards: the taxonomic distinction between specimen and species, individual and group (category). The temporality of the Wajãpi cosmos, which primarily refers to the forest, does not consider specific individual specimens but species as a category that encompasses a group of similar individuals. It is worth remembering here that species is a central notion in Lévi-Strauss' (1966) "savage mind," as it lies halfway between universalisation (categories of gender, family, etc.) and particularisation (individual). The notion of species reunites a complex combination of characters from a group of living beings and operates as a conceptual "instrument" that turns unity into multiplicity and multiplicity into unity (Lévi-Strauss 1966). The jiruru tree that held up the sky is therefore not exactly a single jiruru tree that can be identified at a specific point in the forest. It is rather an ancestral jiruru that virtually possesses all jiruru in itself - it is a singularity that is multiple and a multiple that is on ${ }^{10}$. That is why each and every jiruru indicates the time that the sky fell and allows for the sensible experience of that moment. In short, it is jiruru as a species that operates the act of remembrance.

\footnotetext{
9 Discussions of Wajãpi movement appear in many preceding works with varied analytical scope that consider territorial shifts, successive migrations, linguistic appropriation and cosmological movement (P. Grenand, 1979, 1980; F. Grenand, 1995; Gallois, 1988; and Campbell, 1989).

10 Strathern indicates the productivity of the idea “one that contains many" found among the Gawans: “If 'ones' contain 'many' then one is also a version of many, epitomized in the recapitulation of descent group members as one. [...] Each member contains the group. At the same time, in terms of the capacity for making extensions and connections, each member potentially belongs to a matrix of radiating." (1991: 68).
} 
Meanwhile, memories of social relations - that is, of entwined life stories that are exemplarily remembered through cultivated plants - essentially have specimens as subjects. Specific trees carry the marks of a machete in their bodies indicating the path to the Ypavu lake. A specific pinoe'e palm reminds Parua of her son's childhood. A specific grove of peach-palms located near Aramirã reminds Kumai's family of the deceased chief. Specimens have relational agency, they are not inert supports because they provoke memories and affects in the people with whom they relate - specimens make people recount and affectively remember.

At one extreme we have specimens (individuals) that remember life trajectories and social relations: memories imbued with a dense affective charge due to the proximity of the subjects that they weave together. In the middle are plant lineages, which might last longer than individual specimens but can only be maintained by the latter and by awakening people's interest in continuously (re)planting them" ${ }^{11}$; this is a temporality that is perishable much like people and plants: each has a lifespan - some are centenary like the sumaúma, others are more ephemeral, like a manioc plant - but all of them will die. At the other extreme there are species and genera, categories of beings that lead to a more or less imperishable temporality that always renews itself; in the end, unless predictions about the world's end and destruction are confirmed, there will always be a jiruru tree to remind the Wajãpi of the time that the sky fell, a japu-mucus vine to remind them of Wyrakauri's adventures...

In dialogue with the biological theory of evolution, Gregory Bateson (1979: 103) presents us with an interesting idea about how life tricks death, how a biological system obliterates time. He proposes that while individuals complete their lifecycle and then undo this circuit (by dying), the group maintains itself, the species continues through the reproduction of new individuals and tricks death by extending that lifecycle through the collectivity:

The bamboo bends before the wind', in a Japanese metaphor; and death itself is avoided by a quick change from individual subject to class. Nature, to personify the system, allows old man Death (also personified) to have his individual victims while she substitutes that more abstract entity, the class or taxon

The capacity for transformation is a fundamental factor in this game of life and death in which organisms perpetuate themselves through continual change: processes such as adaptation and natural selection are ${ }^{12}$ mechanisms driven by the plasticity and renewal of living beings, who can cheat death precisely because they do not remain identical through the generations.

We can thus find an echo of Lévi-Strauss' analysis of myth (2004 and 2011) in Darwin's theory of evolution: myths both maintain and obliterate time not because they remain the same throughout the generations that narrate them, but precisely because of their capacity to ceaselessly transform. At the end of the last volume of Mythologiques' the author even recognises a formal similarity between the mythological spiral and life as

\footnotetext{
11 Michael Pollan (2003) points out that the desire (the will to eat, smoke, look at, smell etc.) aroused by plants can be understood as an evolutive disposition related to the perpetuation of these species. In this sense, it means that some plants co-evolve with other species and also act upon them. For example, when a bird or person eats a fruit and spreads its seeds, the plant is not passive in this process for it stimulates these actors' desire. Here we can also evoke Bruno Latour's notion (2001 and 2002) of "make act."

12 It is important to recognise Ingold's (2004) criticisms of the theory of evolution (both in relation to Darwinism and to a more recent evolutionary synthesis, or neo-Darwinism), a critique that focuses on the concepts of natural selection and adaptation. According to Ingold, the greatest problem with these notions is the unidirectional relation between environment and organism. Even though the criticism has grounding in certain contexts, I look to biologists who note and also problematise these aspects and highlight two-way movements. For example, Lynn Margulis (1987) shows how bacteria were fundamental to the formation of the Earth as we know it, emphasising environmental changes caused by life, by the action of organisms. Francisco Varela (1987) notes that adaptation and natural selection should not be reduced to the idea of improvement or survival of the fittest but rather the congruence (a two-way relation) between environmental and organic changes. Ernest Mayr (2001) himself discusses the imprecise use of these concepts, vehemently denying the idea of improvement, highlighting how the interplay between chance and necessity is fundamental for evolution, a process in which environment and organism are in dialogue. I use these terms - risking a certain misunderstanding - because the dialogue with biology seems to be one possible way to de-centralise humanity in anthropological analysis, which was already operating in Charles Darwin's work (see Marras, 2009).
} 
described in D'Arcy Thompson's evolutionist studies about the relations of transformation between different species. The obliteration of time by myths can thus be related to the perpetuation of species in constant transformation (and vice-versa).

\section{Second Twist: Co-Temporalities}

So far, we have closely followed the Wajãpi ethnography, but an analytical shift is now appropriate for us to explore other possible (and partial) connections between Wajãpi and scientific knowledge with the aim of contributing to a post-human discussion in anthropology beyond an Amazonian ethnographic case.

Amerindian perspectivism (Viveiros de Castro 2002, and Lima 1996 and 2005) emerged from Amazonian research (with special emphasis on Tupi-speaking groups such as the Wajãpi), focused on shamanic activity - a practice that makes access to other beings' lived worlds possible. As a result, the central point of perspectivism is that those who possess shamanic substances in their bodies experience a broadly shared humanity and a multiplicity of natures (of bodies and worlds). Shamans are thus inter-specific beings, people with hybrid bodies who can pass between worlds. These propositions make sense in the Wajãpi context: other ethnographies (Gallois 1988 and 1996, Campbel 1989 and Grenand 1980) have confirmed this, describing their shamanic ${ }^{13}$ activities in detail. However, when we look beyond shamanism, it is not the humanity of these other beings that is at stake; or rather, it is not necessarily the human position that is being marked when trees and other plants are treated as if they are endowed with autonomy and agency - taking agency "as a capacity to create and affect particular kinds of relations" (High, 2012: 137).

Even though the aim here is not to critique perspectivism by presenting a potential dissonance between points found in the ethnographic material and the perspectivist model (as in Sulkin, 2005), it is important to state that perspectivism does not always function or appear in all contexts of life in a Wajãpi community. We are faced with "a complex and overlapping matrix of humans and non-humans that interact in different ways. In this light, we might envision Amazonian cosmology and sociality not just as struggle between different co-specifics to assert a generic 'human' perspective over other beings, but also a set of multiple agencies that affect specific relationships in distinct ways" (High, 2012: 137). This allows us to suggest that in Amerindian societiessubjects might not be human as suggested by Viveiros de Castro (op. cit.).

In an effort to conduct a non-anthropocentric anthropology (Kohn 2013) and using an ethnography that is attentive to the ordinary activities that produce life (Overing 1991 and 2006), I hope I have emphasised how, in certain contexts, the interaction between some Wajãpi and other beings (and especially plants) takes place through the absolute recognition of difference between them. These are differences that are noted at moments of corporeal constitution and maturation, and which do not come close to configuring a (backgrounded) common humanity. Such differences present the need to approach the process of elaborating life through the limitations and impositions asserted by these beings; agents that are in and of the relation. It is true that by attributing humanity to all of these beings, perspectivism undoes the notion of humanity, transforming it into a zero signifier. In a different way, perspectivism also points out that humanity is not the centre since it is everywhere. However, the decision to conduct an ethnography beyond mainstream shamanic actions ${ }^{14}$ does not permit a simple adherence to the notion of a shared humanity, and the decision to follow a different path can be explained by a move to de-centre humans.

\footnotetext{
13 Note that ethnographic descriptions about the Wajãpi also served as material for the production of the perspectivist synthesis.

14 I am calling "mainstream shamanic actions" those actions operated by shamans in relation to healing-aggressive systems and hunting. Elsewhere (Cabral de Oliveira 2015) I suggest that shamanism should be situated at a specific point in an agency scale, so that we can include actions by people who are not endowed with powerful shamanic substances, but who have a certain efficacy through their communication with other inhabitants in the cosmos.
} 
Along these lines, Van Dooren (2012) traces relations between certain botanists' arguments and the adaptive changes that some plant species underwent in the domestication and cultivation process. The author shows how our agricultural history can be read in reverse, as a two-way process in which humans were also domesticated by plants. Van Dooren thus highlights that we (humans) have adapted our way of life and bodies to conditions imposed by crops. What is at stake in his argument is not the plants' possible humanity but their fully singular and autonomous agency.

I would like to point out that the emergence of co-temporalities was fundamental in this process of mutual cultivation (to maintain a more appropriate concept for this ethnographic context), that is, the intertwining of distinct life cycles through difference itself: difference between individual times, between group times, and between the life cycles of an individual in relation to a group. There is a necessary composition between times of growth, maturation and life for each of those involved in this game of conviviality: there are species, like manioc and potatoes, that possess a shorter cycle in relation to a human being's average life span, and that seduce (Pollan 2003) humans so that they are constantly cloned and replanted, thus extending their life-cycle through a lineage, through a group. There are also species with a longer cycle that can often be harvested by people from different generations - such as the peach-palm, which produces fruit for approximately 50 to 75 years, with accounts of productive palm trees that are more than one hundred years old (Mora-Urpí et. al. 1997) - which extends their life span through their relation with a group of people (family).

If plants have been given less space in debates about relations between humans and non-humans in anthropology, I suggest that this is largely due to the corporeal difference (to use an essential idiom in Amazonian ontologies) between vegetables and the human animal. These differences speak to the temporality of the life cycles and maturation of botanical species, which are marked by an apparent lack of movement and capacity to vocalize that conjures, for us, the essence of communication. In truth, these functions are not completely absent in vegetables, but are difficult to perceive due to our animal models for movement and the circulation of information. However, certain botanical studies have gone in other directions, making it possible for us to broaden our human-animal centred filters.

My argument is that more important than de-centring humanity is the need to de-centre animality ${ }^{15}$. Recent botanical studies thus show how plants exchange nutrients and information about how to defend themselves against pathogens through networks formed by the mycorrhiza and that connect trees through their roots (Johnson et. al. 2015, Babikova et. al. 2013, Simard 2009). Using terms such as "signs" and "communication" biologists describe complex molecular phenomena that travel through the mycelium web and allow for carbon sequestration, as well as produce defences against insects and fungi attacking neighbouring plants, through the exchange of organic compounds and information. ${ }^{16}$ These studies show the importance of intra and interspecific relations in the evolutionary process, which is best understood as a form of co-evolution. Meanwhile, in anthropology, it is important to note that Tsing (2012 and 2015) has stressed how fungi connect heterogeneous actors - like people, plants, soil, nutrients etc. - in a living network that make them into a "companion species" (Haraway 2003a) for other beings beyond humans.

Donna Haraway and Van Dooren thus both propose that the human is simply another organism that is formed and forms others, or rather, that the concept of co-evolution should be broadened to incorporate humanity; that we should think in terms of co-histories that lead to the emergence of naturecultures

\footnotetext{
15 This discussion is being made by philosophers and botanists: Coccia, 2018 and Mancuso, 2019.

16 Other studies also show communication via volatile molecules that travel through the air or soil, playing a part in a species' defence system. It is also observed that when a specific specimen is attacked by insects and fungi, neighbouring plants might have a faster reaction time and sometimes react even prior to attack (Baluska and Mancuso, 2009).
} 
(Haraway 2003a: 12). In anthropology, this might mean that we should be attentive to the connections that certain humanities make with other beings to constitute their worlds and to describe this process in a manner that considers the conceptions of those that participate in it.

In turn, since its foundation by Darwin, the biological theory of evolution (the naturalistic theory of life) has pointed precisely to relations between various living beings ("the kinship of organic forms"), as well as to life's capacity for transformation. As Mayr (2001:7) argues, Darwin placed a spotlight on the world's inconstancy and illuminated the complexity of life: "the acceptance of evolution meant that the world could no longer be considered merely as the seat of activity of physical laws but had to incorporate history and, more importantly, the observed changes in the living world in the course of time."

By broaching the forms in which plants react to the environment, some botanists speak of "intelligence" to define their capacity for noticing, reacting and communicating information. Plants are thus seen to monitor temperature, gravity, luminosity and humidity, transforming their perception of these factors into chemical and electrical instructions that generate reactions in leaves, roots, branches, etc. (Baluska and Mancuso 2009, Baluska et. al. 2007 and 2009). What these studies point to is that these reactions often go unnoticed by us because we operate at a different time scale: tendril movements, the growth of stems and branches, and the direction taken by roots are too slow and can only be noticed by us once they are complete. Meanwhile, plants move, they recognise and seek out the best supports, the soil with most nutrients, the sun's direction and seduce dispersers that carry their seeds afar. In a different way, the Wajãpi families with whom I have lived recognise distinct temporalities that can be accessed through careful engagements with other beings (these "significant others" to quote Haraway 2003a). As we have seen, in this relationship it is necessary to communicate and respect the differences that each plant presents, and to construct multiple space-times alongside them. ${ }^{17}$

\section{Conclusions}

This article initially sought to show how events in an origin space-time left marks on the bodies of beings that inhabit the current terrestrial platform as mnemonic ties anchored to certain groups (categories). In contrast, individuals - particularly cultivated plants - are central to the constitution of recent memories that are rooted in kinship space-time. The objective was to contribute to an important discussion about space-time in Amazonia beyond an established ritual and shamanic scope, demonstrating how plants and other beings can be subjects that promote spatialized recollections, with emphasis on the operation of sensible aspects (life cycles, maturation and perishability) in this process.

By treating plants as subjects in their relations with Wajãpi families and their production of community life between gardens and forests, it was necessary to question the perspectival maxim that humanity is the form of the subject. The ethnographic excerpts presented indicate the need to understand the subjects through actions, thus corroborating High's (2012) proposal that agency should be defined as the capacity to affect and produce relations.

Faced with this ethnographic framework, and to fully consider the specificities of relations between the Wajãpi and plants, one option is to appeal to a post-human anthropology. By de-centring the human animal in the analysis it became possible to, firstly, conduct a descriptive experiment that is aligned with this recent theoretical proposal and, secondly, to understand that what is at stake is precisely the constitution of relations through significant differences between life cycles. As they articulate temporalities diverse to our own,

17 Kohn (2013) recently reviewed and developed the idea of a broad theory of communication. He presents a semiotic analysis that includes non-humans and treats sign processes as inherent to life. Kohn also describes cross-species communication among the Runa beyond shamanic actions. Despite these interesting contributions, and while his work has been an important inspiration to my own recent work, instead of applying his analytical proposal based on Charles Pierce's theories, I would rather follow an immanent Wajãpi theory. 
due to their apparently fixed and silent character, the agentive power of plants has been given little import. This is why it was important to call upon botanical studies that look at plants through their own spatio-temporal scales. Accordingly, as the Wajãpi and various botanists teach us, this article sought to ethnographically establish that vegetable action can and should be noticed in its alterity.

Submitted: November 12, 2019

Accepted: April 29, 2020

Translated by Jeffrey Hoff

\section{Bibliography}

BABIKOVA, Z. L.; GILBERT, T. A. B.; BRUCE, M.; BIRKETT, J. C.; CAULFIELD, C.; WOODCOCK, J. A.;

PICKETT, D.; JOHNSON. 2013. "Underground signals carried through common mycelial networks warn neighbouring plants of aphid attack”. Ecology Letters, 16: 835-843.

BALUSKA, F.; MANCUSO, S. 2007. "Plant neurobiology as a paradigm shift not only in the plant sciences". Plant Signaling \& Behavior, 2(4): 205-207. . 2009. "Plant neurobiology: from sensorybiology, via plant communication, to social plant behavior". Cognitive Process, 10(Suppl 1): 3-7.

BALUSKA, F.; MANCUSO, S.; VOLKMANN, D.; BARLOW, P. 2009. “The root-brain hypothesis of Charles and Francis Darwin”. Plant Signaling \& Behavior, 4(12): 1121-1127.

BATESON, G. 1979. Mind and Nature. A necessary unity. New York: E. P. Dutton. . 1972. Steps of an ecology of mind. London: Jason Aronson Inc, Nothvale.

CABRAL, M. P. 2014. No tempo das pedras moles. Ph.D. Thesis, Universidade Federal do Pará.

CABRAL DE OLIVEIRA, J. 2012. Entre plantas e palavras. Ph.D. Thesis, Universidade de São Paulo. . 2009. "Social Networks and Cultivated Plants: Exchange of Planting Materials and Knowledge".

Tipiti, 6(2): 101-110.

. 2015. "Ensaio sobre práticas cosmopolíticas entre famílias wajãpi. Sobre a imaginação, o sensível, o xamanismo e outras obviedades". Mana. Estudos de Antropologia Social, 21(2): 297-322.

CAMPBEL, A. T. 1989. To square with genesis. Edinburgh: Edinburgh University Press.

COCCIA, E. 2018. A vida das plantas. São Paulo: Cultura e Barbárie.

FAUSTO, C. 2008. "Donos demais: maestria e domínio na Amazônia”. Mana. Estudos de Antropologia Social, $14(2): 329-366$.

GALLOIS, D. T. 1993. Mairi revisitada. A reitegração da fortaleza de Macapá na tradição oral dos Waiãpi. São Paulo: NHII/USP e Fapesp. . 1988. O movimento na cosmologia waiapi: criação, expansão e transformação do universo. Ph.D. Thesis, Universidade de São Paulo. . 1996. "Xamanismo waiãpi: nos caminhos invisíveis, a relação i-paie". In: Esther Jean Langdon (org.), Xamanismo no Brasil. Novas perspectivas. Florianópolis: UFSC. pp. 39-74. 
GARCIA, U. 2010. Karawara. A caça e o mundo dos Awá-Guajá. Ph.D. Thesis, Universidade de São Paulo, São Paulo.

GELL, A. 1998. Art and Agency: An Anthropological Theory. Oxford University Press, Oxford.

GRENAND, P. 1979. “Commentaires à propos d'un abattis wayãpi”. Cahiers Sciences Humaines, ORSTOM, XVI(4): 299-303. .1980. Introduction a l'Étude de l'Univers Wayãpi. Paris: Centre National de la Recherche Scientifique.

GRENAND, F. 1995. "Les Voyage des mots. Logique de la nomination des plantes: exempledans des langues tupi du Brésil”. Revue d'Ethnolinguistique, 7: 23-42.

GOW, P. 2001. An amazonian myth and its history. Oxford: Oxford University Press.

HARAWAY, D. 2003a. The companion species manifesto: dogs people and significant otherness. Chicago: Prickly Paradigm Press. . 2003b. When species meet (posthumanities). New York: Paperback.

HIGH, C. 2012. "Shamans, animals and enemies: human and non-human agency in an Amazonian cosmos of alterity”. In: Marc Brightman, Vanessa Grotti and Olga Ulturgasheva (eds.), Animism in rain forest and tundra. London: Berghahn books: 130-145.

HUGH-JONES, C. 1979. From the milk river: spatial and temporal processes in Northwest Amazonia. Cambridge: Cambridge University Press.

HUGHES, Aaron. 2002. "Imagining the di- vine: Ghazali on imagination, dreams, and dreaming". Journal of the Ameri- can Academy of Religion, 70(1):33-53.

INGOLD, T. 2000. The perception of the environment. Essays on livelihood, dwelling and skill. Londres: Routledge. . 2004. "Beyond biology and culture: the meaning of evolution in a relational world". Social Anthropology, 12(2): 209-221. . 2013. "Dreaming of dragons: on the imagination of real life". Journal Royal Anthropological Institute, 19(4): 734-752.

JOHNSON, D.; GILBERT, L. 2015. "Interplant signalling through hyphen networks". New Phytologist, 205: 1448-1453.

KOHN, E. 2013. How forests think: toward an anthropology beyond the human. New York: Paperback.

LATOUR, B. 2001. A esperança de Pandora. Bauru: EDUSC. . 2002. Reflexão sobre o culto moderno dos deuses fe(i)tiches. Bauru: EDUSC.

LÉVI-STRAUSS, C. 1966. The savage mind. Chicago: University of Chicago Press. . 2004. O Cru e o Cozido. São Paulo: Cosac e Naify. . 2011. O Homem Nu. São Paulo: Cosac e Naify.

LIMA, T. S. 1996. “O dois e seu múltiplo. Reflexões sobre o perspectivismo em uma cosmologia Tupi”. Mana. Estudos de Antropologia Social, 2(2): 21-47. 2005. Um peixe olhou para mim. São Paulo: Ed. Unesp.

MARGULIS, L. 1987. “Os primórdios da vida”. In: William I. Thompson (ed.), Gaia. Uma teoria do conhecimento. São Paulo: Ed. Gaia. pp. 30-42.

MARRAS, S. 2009. Recintos e evolução: capítulos de antropologia da ciência e da modernidade. Ph.D. Thesis, Universidade de São Paulo.

MANCUSO, S. 2019. A revolução das plantas. São Paulo: Ubu. MAYR, E. 2001. O que é evolução? Ed. Rocco, São Paulo. 
MORA-URPÍ, J.; WEBER, J. C. and CLEMENT, C. R. 1997. Peach palm. Bactris gasipaes Kunth. Promoting the conservation and use of underutilized and neglected crop 20. Rome: Institute of Plant Genetics and Crop Plant Research, Gatersleben/ International Plant Genetic Resources Institute.

MOSKO, M. 2009. "The fractal yam: botanical imagery and human agency in the Trobriands".

JRAI, 15(4): 679-700.

MURRIETA, R. S. S.; WINKLERPRINS, A. 2003. "Flowers of Water: Homegardens and Gender Roles in a Riverine Caboclo Community in the Lower Amazon, Brazil". Culture \& Agriculture, 25(1): 35-47.

OVERING, J. 2006. "O fétido odor da morte e os aromas da vida. Poética dos saberes e processo sensorial entre os Piaroa da bacia do Orinoco". Revista de Antropologia, 49(1): 19-54. . 1991. "A estética da produção: o senso de comunidade entre os Cubeo e os Piaroa". Vol. 34: 7-33.

POLLAN, M. 2003. The botany of desire. New York: Bloomsbury.

RIVAL, L. 1993. "The Growth of Family Trees: Huaorani Conceptualization of Nature and Society”. Man, 28(4): 635-652. . 1998. "Domestication as a historical and symbolic process: wild gardens and cultivated forests in the Ecuadorian Amazon”. In: William Balée (ed.), Principles of Historical Ecology. New York: Columbia University Press. pp. 232-250. . 2001. "Seed and clone: the symbolic and social significance of bitter manioc cultivation". In: Laura Rival and Neil Whitehead (eds.), Beyond the visible and the material: the amerindization of society in the work of Peter Rivière. Oxford: Oxford University Press: 57-79.

SANTOS-GRANEIRO, F. 2009. "Introduction”. In: __. (ed.), The occult life of things. Tucson: The University of Arizona Press, 1-29.

SAEZ, O. C. 2005. "A terceira margem da história: estrutura e relato das sociedades indígenas".

Revista Brasileira de Ciências Sociais, Vol.20, n.57: 39-51.

SULKIN, C. L. 2005. "Inhuman Beings: Morality and Perspectivism among Muinane People (Colombian Amazon)". Ethnos, 70-1: 1-33.

STRATHERN, M. 1991. Partial connections. Oxford: AltaMira Press.

SIMARD, S. W. 2009. "The foundational role of mycorrhizal networks in self-organization of interior

Douglas-fir forests". Forest Ecology and Management, 2009: 95-107.

THOMPSON, W. I. 1987. "Prefácio”. In: William I. Thompson (ed.), Gaia. Uma teoria do conhecimento. São Paulo: Ed. Gaia. pp. 1-7.

TSING, A. 2012. "Unruly edges: mushrooms as companion species". Environmental humanities, 1: 141-154. . 2015. The Mushroom at the end of the World. Princeton University Press, New York.

VARELA, F. 1987. "O caminhar faz a trilha”. In: William I. Thompson (ed.), Gaia. Uma teoria do conhecimento. São Paulo: Ed. Gaia: 45-6o.

VAN DOOREN, T. 2012. "Wild seed, domesticated seed. Companion species and emergence of agriculture". Philosophy, Activism, Nature, 9: 22-28. . 2011. "Vultures and their people in India: Equity and entanglement in a time of extinctions". Australian Humanities Review, 50: 45-61.

VAN VELTHEM, L. H. 2003. O Belo é a Fera. A Estética da Produção e da Predação entre os Wayana. Lisboa: Assírio e Alvim.

VIVEIROS de CASTRO, E. 2002. A inconstância da alma selvagem. São Paulo: Cosac \& Naify. 


\section{Acknowledgements}

I am grateful to FAPESP for the post-doctoral grant (2014/13249-o) that made this work possible. I am also grateful to Igor Scaramuzzi and Marilena Arruda Campos for their comments and for the dialogue initiated with my supervisors Dr Rui Murrieta and Dr Laura Rival, during my post-doctoral studies. Finally, I would like to acknowledge Julia Sauma's translation of this article.

Joana Cabral de Oliveira

Professor of the Department of Anthropology, State University of Campinas, Brazil https://orcid.org/0000-0002-4308-8562

Author's email: jcdo@unicamp.br 